recorded during any of the tests apart from occasional mild hypoglycaemic symptoms attributable to insulin.

Plasma Metiamide Concentrations.-In the five subjects studied with tritium-labelled metiamide the mean plasma concentration 60 minutes after the start of the infusion was 7.09 $\mu \mathrm{mol} / 1$. (range $6 \cdot 18-8.65 \mu \mathrm{mol} / \mathrm{l}$.).

\section{Discussion}

Though histamine $\mathrm{H}_{2}$ receptor antagonists clearly inhibit both histamine-induced and pentagastrin-induced gastric secretion there has been some uncertainty concerning their effects on vagally-induced secretion. In their description of the properties of the first $\mathrm{H}_{2}$ receptor blocking agent, burimamide, Black et al. (1972) observed no inhibition of carbachol-stimulated gastric secretion in the rat. In the fistula dog, however, metiamide has been shown to inhibit vagally induced gastric secretion when 2-deoxy-D-glucose was used as the stimulant (Grossman and Konturek, 1973). Our own results now show conclusively that metiamide also inhibits vagally-stimulated acid secretion in man, with reduction of both the volume and acid concentration of the gastric juice.

Metiamide thus inhibits acid secretion evoked in man by the three major agonists-histamine, gastrin, and acetylcholine. At first sight this lends support to the theory of MacIntosh (1938) that histamine serves as the "final common pathway" in the mediation of the gastric secretion since specific blockade of the histamine receptor would be expected to inhibit the effect of gastric secretory stimuli acting through histamine but not those independent of it. Grossman and Konturek (1973) have suggested, however, that the three major agonists each bind to a specific receptor site on the parietal cell and that blockade of one receptor may modify the response of one or both the other receptors to their respective agonists. Consistent with this hypothesis is the observation that cholinergic blockade by atropine inhibits secretion induced by histamine or pentagastrin (Konturek et al., 1968), and histamine $\mathrm{H}_{2}$ receptor blockade by metiamide may thus inhibit vagally mediated gastric secretion by a similar mechanism of receptor interaction. The effect of metiamide on vagally induced secretion would seem, however, to be more substantial than that of atropine on histamine-induced secretion, suggesting that functional integrity of the histamine receptor may have a particular importance. Thus the role of histamine in the physiology of gastric secretion is still controversial though it seems likely that further work with $\mathrm{H}_{2}$ receptor antagonists will enhance our understanding of the problem.

Regardless of the physiological implications of $\mathrm{H}_{2}$ receptor blockade the efficacy of metiamide as an inhibitor of acid secretion raises the question of its therapeutic potential. In the present studies the inhibition of acid secretion has been achieved at plasma metiamide concentrations comparable with those which follow a $300-\mathrm{mg}$ oral dose of the drug (unpublished observations). One possible limitation to the value of metiamide in the treatment of peptic ulceration, however, relates to its effect on pepsin secretion. Our own preliminary studies in man and those of Hirschowitz and Gibson (1973) in the fistula dog suggest that pepsin secretion in response to cholinergic stimuli may be unaffected or even increased by metiamide. Nevertheless, on satisfactory conclusion of current toxicity trials formal therapeutic trials will be indicated to assess the value of metiamide in peptic ulcer therapy.

We thank Dr. A. C. Flind of Smith, Kline and French Laboratories Limited for supplies of metiamide; Mrs. B. Beck for her help in preparing this manuscript; and Professor A. P. M. Forrest for his support.

\section{References}

Ash, A. S. F., and Schild, H. O. (1966). British fournal of Pharmacology, $27,427$.

Black, J. W., et al. (1972). Nature, 236, 385.

Carter, D. C., Dozois, R. R., and Kirkpatrick, J. R., (1972). British Medical

Fournal, 1, 202.
Grossman, M. I., and Konturek, S. J. (1973). International Symposium on

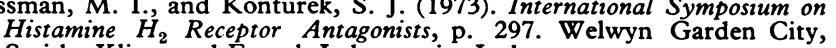
Smith, Kline, and French Laboratories Ltd.

Hassan, M. A., and Hobsley, M. (1970). British Medical fournal, 1, 458.

Hesselbo, T. (1973). In International Symposium on Histamine $\mathrm{H}_{2}$ Receptor Antagonists; ed. C. J. Wood and M. A. Simkins, p. 29. Welwyn Garden City, Smith, Kline and French Laboratories Ltd.

Hirschowitz, B. I., and Gibson, R. (1973). International Symposium on Histamine $\mathrm{H}_{2}$ Receptor Antagonists, ed. C. J. Wood and M. A. Simkins, p. 273. Welwyn Garden City, Smith, Kline and French Laboratories p. 273.

Konturek, S. J., Oleksy, J., and Wysocki, A. (1968). American fournal of Digestive Diseases, 13,792 .

MacIntosh, F. C. (1938).Quarterly fournal of Experimental Physiology, 28, 87.

Wyllie, J. H., and Hesseibo, T. (1973). International Symposium on Histamine $\mathrm{H}_{2}$ Receptor Antagonists, p. 371. Welwyn Garden City, Smith, Kline and French Laboratories Ltd.

\title{
Oral Contraceptives and Increased Formation of Soluble Fibrin
}

\section{O. PILGERAM, J. ELLISON, G. VON DEM BUSSCHE}

British Medical fournal, 1974, 3, 556-558

\section{Summary}

Soluble fibrin was measured weekly for two months in 12 normal women and in 12 women on combined oestrogenprogestogen therapy (Ortho-Novin, Norinyl, Enavid, Ovral, Ovulen, Demulen). Plasma soluble fibrin concen-

\footnotetext{
Coagulation Laboratory, Baylor College of Medicine, Texas Medical Center, Houston, Texas 77025, U.S.A.

L. O. PILGERAM, PH.D., Director

J. ELLISON, M.S., Research Assistant

G. VON DEM BUUSSCHE, M.s., Research Assistant
}

tration in women on oral contraceptives showed an increase of $97.2 \%(P<0.001)$ above that of normal women. In three cases, where each woman on the oral contraceptive.served as her own control, stopping medication led to a return to normal of the plasma content of soluble fibrin.

\section{Introduction}

A similarity between the magnitude and the direction of changes in blood clotting and thrombolytic factors in patients with thrombosis and in women using oestrogen- and progestogenbased oral contraceptives was reported 10 years ago (Pilgeram, 1964; Pilgeram and Amundson, 1964; Pilgeram et al., 1964). 
Later studies by Jeffcoate et al. (1968) found a tenfold increase in thromboembolism in patients over 35 years of age. Inman and Vessey (1968) reported a sixfold to sevenfold increase in cerebral thrombosis. A recent collaborative study has shown the risk of cerebral thrombosis or ischaemia to be about nine times greater for women who use oral contraceptives than for those who do not (Collaborative Group Study of Stroke in Young Women, 1973). The National Heart and Lung Institute Coronary Drug Study (Coronary Drug Study Research Group, 1970) on the effect of oestrogens on myocardial infarction was suspended because of a higher rate of reinfarction, pulmonary embolism, and thrombophlebitis in the patient group treated with oestrogens. All of these data indicate that an imbalance in the plasma content of oestrogens, and possibly, progestogens will favour blood clotting and thrombosis. We report here that various combinations of oestrogens and progestogens induce a significant increase in the intravascular conversion of fibrinogen to a derivative with a property which can be induced in vitro by thrombin. Cessation of medication with the "pill" induced a return to normal of the plasma fibrinogen derivative.

\section{Patients and Methods}

\section{STUDY GROUPS}

Two groups of female volunteers were studied. The first group consisted of 12 women aged 18-32 (mean ( \pm S.D.) $25 \cdot 8 \pm 4 \cdot 4$ years) who were on combined oestrogen-progestogen therapy for six or more months as described in table I. The drugs were taken from day five of the menstrual cycle to day 24 or 25 . The second group consisted of 12 women aged 14-31 (mean ( \pm S.D.) $22.8 \pm 3.9$ years) who were not on oral contraceptive therapy and had not taken any oral contraceptives for at least six months previously. A third group consisted of 12 men aged 22-48 (mean ( \pm S.D.) $28 \pm 7.6$ years). Blood samples were drawn weekly for two months from both groups of women volunteers.

TABLE I-Types and Constituents of Oral Contraceptives taken by 12 Women Studied

\begin{tabular}{|c|c|c|}
\hline Proprietary Name & Tablet Composition & $\begin{array}{c}\text { No. of } \\
\text { Subjects }\end{array}$ \\
\hline Ortho-Novin $1 / 50$, Norinyl-1 & 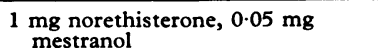 & 4 \\
\hline Ortho-Novin $1 / 80$ & $\begin{array}{l}1 \mathrm{mg} \text { norethisterone, } 0.08 \mathrm{mg} \\
\text { mestranol }\end{array}$ & 3 \\
\hline Ovral & $\begin{array}{l}0.5 \mathrm{mg} \text { norgestrel, } 0.05 \mathrm{mg} \\
\text { ethinyloestradiol }\end{array}$ & 2 \\
\hline Enavid & $\begin{array}{l}5 \text { mg norethynodrel, } 0.075 \mathrm{mg} \\
\text { mestranol }\end{array}$ & 1 \\
\hline Demulen & $1 \mathrm{mg}$ ethynodiol diacetate, $0.05 \mathrm{mg}$ & 7 \\
\hline Ovulen & 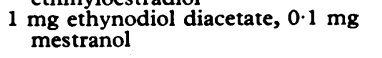 & 1 \\
\hline
\end{tabular}

Three women from the first group (age range 22-26; mean 25 $\pm 2 \cdot 7$ years) discontinued oral contraceptive therapy during the study. The plasma levels of fibrinog'.1, soluble fibrin, plasminogen activator, and partial thromboplastin time were monitored in these patients for one to two months after cessation of medication.

To compare values at different points during the menstrual cycle the first day of menstruation was considered day 1 of the cycle and the following correction was made for subjects who did not have 28-day cycles. (Day in subject's cycle/Length of subject's cycle) $\times 28=$ equivalent day in 28 -day cycle. The mean of all the assays were calculated for the purpose of arriving at tabular data. The mean variation during the cycle was determined for appropriate time ordinates.

\section{ASSAY TECHNIQUES}

Venous blood $(2.25 \mathrm{ml})$ was combined with $0.25 \mathrm{ml}$ of an anticoagulant mixture containing $2 \%$ edetic acid and $10 \mathrm{mg} / \mathrm{ml}$ of crystalline soya bean trypsin inhibitor (Sigma Chemicals, St. Louis, Mo.) for the determination of the concentration of the soluble fibrin monomer. Assay for soluble fibrin was performed according to a method previously reported by this laboratory (Pilgeram et al., 1973) and similar to that of Kisker and Rush (1971). For other assays $4.5 \mathrm{ml}$ of blood were drawn into plastic syringes and mixed with $0.5 \mathrm{ml}$ of $0.1 \mathrm{M}$ sodium citrate. Blood was kept at $2^{\circ} \mathrm{C}$ until all assays were performed within one hour of blood collection. An aliquot of blood, $0.6 \mathrm{ml}$, was added to $5 \cdot 1 \mathrm{ml}$ of cold $\left(2^{\circ} \mathrm{C}\right)$ phosphate buffer $(\mathrm{pH} 7.4)$ for determination of dilute blood clot lysis time (Fearnıey, 1964). Plasma samples were assayed for fibrinogen concentration according to a method previously reported by this laboratory (Pilgeram, 1961). Partial thromboplastin time (P.T.T.) was measured according to the method of Proctor and Rapaport (1961). The procedure for dilute blood clot lysis was based on the technique of Fearnley (1964).

\section{Results}

ORAL CONTRACEPTIVE INDUCTION OF A FIBRINOGEN DERIVATIVE WITH INCREASED UPTAKE OF $1{ }^{-14} \mathrm{C}$-GLYCINE ETHYL ESTER

Medication with the oral contraceptive induced a mean increase of $97.2 \%(\mathrm{P}<0.001)$ in the ${ }^{14} \mathrm{C}$ radioisotopic labelling of the fibrinogen derivative soluble fibrin above that found in the control women (table II). The magnitude of this increase was variable during the 28 -day cycle with peaks of activity being reached about the 11 th and 28 th days of the cycle (see fig.).

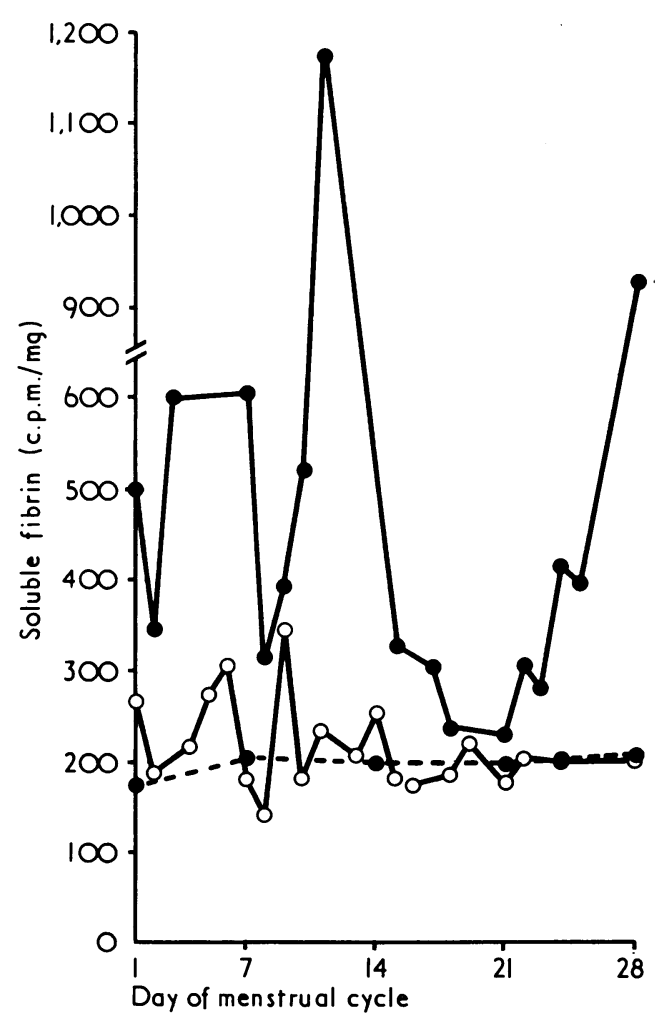

Increase in soluble fibrin induced by oestrogen-based oral contraceptives. - - Women on contaceptives. oral contraceptives. - Female controls. - - - - Male controls.

During the first 14 days of the cycle there was a similarity between the patterns of activity of the normal female group and the group on the pill except for the notably higher level of soluble fibrin in the medicated group.

With 291 c.p.m. as the upper limit of normal for this study only $11 \%$ of the values for the normal women were over this 
threshold whereas $58 \%$ of the values for the women on the pill exceeded the threshold point. All other values for both groups fell below the threshold. Of those women on the combination containing ethinyloestradiol, $63 \%$ of the values exceeded the threshold of 291 c.p.m. and the remaining 37\% fell below it. All normal men had values less than 291 c.p.m. The women on the mestranol component showed a $86 \% \quad(P<0.001)$ increase whereas those on ethinyloestradiol showed a $131 \%$ increase above their female controls (table II).

TABLE II-Plasma Levels of Soluble Fibrin in Male and Female Controls and in Women on Oestrogen-Progestogen Oral Contraceptives

\begin{tabular}{|c|c|c|c|}
\hline & \multirow{2}{*}{ No. Tested } & \multicolumn{2}{|c|}{ Fs (c.p.m./mg fibrin) } \\
\hline & & Mean \pm S.D. & Range \\
\hline $\begin{array}{lll}\text { Male controls } \ldots & \ldots & \ldots \\
\text { Female controls } & \ldots & \ldots \\
\text { Women on oral contraceptives } \\
\text { On mestranol } \\
\text { On ethinyloestradiol }\end{array}$ & $\begin{array}{r}12 \\
12 \\
12 \\
9 \\
3\end{array}$ & $\begin{array}{l}150 \pm 71 \\
221 \pm 54 \\
436 \pm 130 \\
410 \pm 98 \\
511 \pm 206\end{array}$ & $\begin{array}{c}42-246 \\
151-326 \\
66-1888 \\
66-1598 \\
169-1888\end{array}$ \\
\hline
\end{tabular}

EFFECT OF DISCONTINUING ORAL CONTRACEPTIVE THERAPY IN THREE SUBJECTS

Three women were studied during oral contraceptive therapy and for one to two months after stopping treatment for a total of 24 data points during treatment and 18 after cessation. Soluble fibrin values decreased from a mean of 564 (range 66-1888) c.p.m./mg to 266 (156-376) c.p.m./mg-a decrease of $53 \%$ $(\mathbf{P}<0.005)$. Fibrinogen levels averaged $2.57(1.8-3.5) \mathrm{mg} / \mathrm{ml}$ during therapy and $2 \cdot 13(1 \cdot 0-2 \cdot 5) \mathrm{mg} / \mathrm{ml}$ after discontinuance of therapy $-a 17 \%(P<0.002)$ decrease. P.T.T. decreased from $56.8(42-68) \mathrm{sec}$ to $49 \cdot 1(41-59) \mathrm{sec}-\mathrm{a} 14 \%(\mathrm{P}<0.01)$ shortening of clotting time. Clot lysis increased significantly from $2 \cdot 3(1 \cdot 5-3 \cdot 5)$ optical density to $3 \cdot 9$ (3-6) optical density-a $70 \%$ $(\mathrm{P}<0.001)$ improvement.

\section{Discussion}

The principal question posed by these studies concerns the significance of an increased uptake of a $1{ }^{14} \mathrm{C}$-glycine ethyl ester into a fibrinogen derivative (soluble fibrin) with a property similar to that induced in vitro by thrombin. Activated factor XIII is essential for the uptake of the ester into soluble fibrin. Fibrinogen is not significantly labelled. Previous incubation of plasma with low levels of thrombin, $10^{-5}$ to $10^{-2}$ units, will increase the level of specific activity in fibrin several-fold. These experiments indicate that a thrombin-altered fibrinogen (soluble fibr'n) is being measured by the assay technique (Pilgeram and von dem Bussche, 1973; Pilgeram et al., 1973) and that the oestrogen-progestogen preparation also induces this alteration.

The requirement for fibrin stabilizing factor (factor XIII) suggests that the glycine ethyl ester is entering into an amide linkage since factor XIII is also known to act as a transpeptidase. It has been reported that an inhibitor of factor XIII or high concentrations of edetic acid $(40 \mathrm{mmol} / \mathrm{l}$.) will inhibit the formation of polymers of fibrin (Kierulf, 1973). In our laboratory a concentration of edetic acid at $40 \mathrm{mmol} / \mathrm{l}$. will also inhibit the introduction of the ester label. This observation suggests that the soluble fibrin assay may be labelling the same terminal amino groups as are involved in the formation of polymers. The availability of the $\mathrm{NH}^{2}$ group for amide formation, however, indicates that the labelled group is not bound in a polymeric cross linkage. The effect of thrombin on inducing an increase in the labelling of soluble fibrin suggests that the soluble fibrin assay is primarily labelling N-terminal amino groups of glycine released by the action of thrombin on fibrinogen. If this thesis is correct then the assay serves as a direct measure of thrombin activity. On the basis of the preceding considerations it is reasonable to conclude that the oestrogen-based oral contraceptive is responsible for an enhanced conversion of fibrinogen to fibrin. This conclusion also receives support from the cyclical changes in the plasma level of soluble fibrin. The subjects on the contraceptive showed their maximum yields of soluble fibrin about the 11th day and then again about the 24th to the 28th day in the steriod group. Production of oestrogen and progesterone are known to fluctuate with the menstrual cycle. In normally menstruating women the oestrogen excretion shows two maxima during the menstrual cycle, one around the 13th day and one preceding the onset of menstruation (Heftmann and Mosettig, 1960).

These observations of an increase in the plasma level of soluble fibrin, as measured by the $-1{ }^{14} \mathrm{C}$-glycine ethyl ester technique, together with the chromatographic shift to higher molecular weight fibrinogen derivatives described by Fletcher et al. (1972) provide direct evidence that the oral contraceptive, and perhaps other steriods as well (Chatterjea and Solomon, 1954; DeNicola, 1954; Fazlullah, 1956), induce an increased rate of intravascular formation of fibrin.

This work was supported by grant NS 09287-02 from the National Institute of Neurological Diseases and Stroke, Bethesda, Maryland and by the Baylor Neurology Development Fund.

Requests for reprints should be addressed to: Dr. L. O. Pilgeram, Coagulation Laboratory, Department of Neurology, Baylor College of Medicine, 1200 Moursund, Houston, Texas 77025.

\section{References}

Chatterjea, J. B., and Solomon, L. (1954). British Medical fournal, 2, 790. Collaborative Group Study of Stroke in Young Women. (1973). New England fournal of Medicine, 288, 871.

Coronary Drug Project Research Group. (1970). Fournal of the American Medical Association, 214, 1303.

DeNicola, P. (1954). Schweizerische Medizinische Wochenschrift, 84, 835.

Fazlullah, S. (1956). Postgraduate Medical fournal, 32, 444.

Fearnley, G. R. (1964). Fournal of Clinical Pathology, 17, 307.

Fletcher, A. P., Alkjaersig, N., and O'Brien, J. (1972). Proceedings of King's College Hospital Symposium on Venous Thromboembolism, ed. V. V. Kakkar. London, Churchill.

Hachemistry of Steriods, p. 161 New York, Reinhold Publishing Corporation.

Inman, W. H. W., and Vessey, M. P. (1968). British Medical fournal, 2, 193.

Inman, W. H. W., and Vessey, M. P. (1968). British Medical fourn

Jeffcoate, T. N. A., et al. (1968). British Medical
Kierulf, P. (1973). Thrombosis Research, 3, 613 .

Kisker, C. D., and Rush, R. J. (1971). Clinical Investigation, 50, 2235.

Pilgeram, L. O. (1961). Fournal of Applied Physiology, 16, 660.

Pilgeram, L. O. (1964). British Medical fournal, 1, 883.

Pilgeram, L. O., and Amundson, B. A. (1964). Thrombosis et Diathesis Haemorrhagica, 10, 401.

Pilgeram, L. O., Amundson, B. A., and Lofgren, P. E. (1964). Thrombosis et Diathesis Haemorrhagica, 11, 94.

Pilgeram, L. O., Chee, A., and von dem Bussche, G. (1973). Stroke, 4, 643.

Pilgeram, L.O., and von dem Bussche, G. (1973). In Symposium-Radioisotope Techniques in Blood Coagulation and Fibrinolysis. 4th International Congress on Thrombosis and Hemostasis, Vienna, Austria.

Proctor, R. R., and Rapaport, S. I. (1961). American fournal of Clinical Pathology, 36, 212. 